\begin{tabular}{|l|l|l||}
\hline \multicolumn{2}{|c|}{ PublisherInfo } \\
\hline \hline PublisherName & $:$ & BioMed Central \\
\hline \hline PublisherLocation & $:$ & London \\
\hline \hline PublisherImprintName & $:$ & BioMed Central \\
\hline \hline
\end{tabular}

\title{
William L. Russell dies
}

\begin{tabular}{|l|l|l||}
\hline \multicolumn{2}{|c|}{ ArticleInfo } \\
\hline \hline ArticleID & $:$ & 4821 \\
\hline \hline ArticleDOI & $:$ & $10.1186 /$ gb-spotlight-20030731-01 \\
\hline \hline ArticleCitationID & $:$ & spotlight-20030731-01 \\
\hline \hline ArticleSequenceNumber & $:$ & 173 \\
\hline \hline ArticleCategory & $:$ & Research news \\
\hline ArticleFirstPage & $:$ & 1 \\
\hline \hline ArticleLastPage & $:$ & 3 \\
\hline \hline & & RegistrationDate : 2003-7-31 \\
\hline ArticleHistory & $:$ & OnlineDate \\
\hline ArticleCopyright & $:$ & BioMed Central Ltd2003-7-31 \\
\hline \hline ArticleGrants & $:$ & \\
\hline \hline ArticleContext & $:$ & 130594411 \\
\hline \hline
\end{tabular}


William L. Russell, whose tests on mice led to the development of standards for acceptable levels of human exposure to radiation, died at home in Oak Ridge, Tenn., on July 23. He was 92.

An internationally recognized geneticist, Russell spent most of his career at Oak Ridge National Laboratory (ORNL), focusing on the genetic effects of radiation and, later, of chemicals. His research led to important discoveries about occupational exposure to radiation and exposure to atomic weapons.

"All the standards for risk estimates of exposure to certain radiation and a lot of chemicals to humans was based on Bill's work," said Dabney Johnson, group leader for mammalian genetics at ORNL. "Everything the Atomic Energy Commission and all the international oversight commissions use is from data gained from this program."

Born in Newhaven, England, in 1910, Russell graduated Oxford University with a degree in zoology. In 1937, he earned a doctorate in zoology from the University of Chicago, where he studied under Sewell Wright, widely considered the father of population genetics. Russell became a researcher at the Jackson Laboratory, a private animal research facility in Maine, where he met his first wife, Elizabeth. The couple had four children, but the marriage ended in divorce.

In 1947, Russell took a job as principal geneticist and chief of the Mammalian Genetics and Genomics Program at Oak Ridge, a leading atomic research laboratory. He remained at ORNL until retiring in 1977.

Russell's second wife, Liane, was a student in his lab. The two would become one of the most distinguished couples in genetic science. They oversaw the lab's mouse colony, nicknamed "the Mouse House." In 2001, Oak Ridge dedicated a new building for mouse research, called the William L. and Liane B. Russell Laboratory for Comparative and Functional Genomics.

In 1973, Russell was elected a member of the National Academy of Sciences, and in 1976, he received the Enrico Fermi Award, one of the government's most prestigious science awards. He was honored for his major contributions to genetic theory and for his efforts to evaluate the mutagenic potential of chemical pollutants.

Three years later, Russell, though retired, led a team which reportedthat the chemical ethylnitrosourea was far more likely than radiation to cause mutations during experiments.

But Russell wasn't all work and no play. Johnson, a personal friend as well as colleague, said that Russell had no problem leaving work behind and enjoying the weekends. Russell and his wife were committed environmentalists who enjoyed hiking and canoeing.

"He and Liane sort of singlehandedly saved two wonderful river recreational environments in Tennessee," Johnson recalled. "That was as much a part of Bill as the genetics of mice."

Nor would Russell abide mistreatment or painful experimentation on the animals in his lab. 
"Bill would have objected to anything that brought pain or suffering to animals," Johnson said. "He wouldn't cut down a tree, and I don't think he would have felt anything but a warm feeling for any living creature. That's just the way he was. He felt we were all on this planet together."

Russell is survived by his wife, Liane, three children from his first marriage, and two children from his second marriage. A son from his first marriage died in 1994.

\section{References}

1. Sewell Wright Institute of Quantitative Biology \& Evolution, [http://www.stat.wisc.edu/wright/]

2. Elizabeth Schull Russell obituary, Ellsworth American, May 28, 2001., [http://www.ellsworthamerican.com/archive/obit2001/05-01/ea_obit04_05-31-01.html]

3. Oak Ridge National Laboratory Mammalian Genetics and Genomics Program, [http://bio.lsd.ornl.gov/mgd/]

4. Pennisi E: List of National Academy of Sciences married couples The Scientist, 4:7, November 26, 1990., [http://www.the-scientist.com/yr1990/nov/list_901126.html]

5. Parson P: Mouse house renamed for distinguished ORNL couple The Oak Ridger, November 14, 2001., [http://www.oakridger.com/stories/111401/new_1114010024.html]

6. William L. Russell, 1976: Enrico Fermi Awards, [http://www.pnl.gov/fermi/citations/russell-cit.html]

7. Specific-locus test shows ethylnitrosourea to be the most potent mutagen in the mouse

This PDF file was created after publication. 